Vol. 59, z. 12006

s. 213221

\title{
The share of nectariferous and polleniferous taxons in chosen patches of thermophilous grasslands of the Lublin Upland
}

\section{${ }^{1}$ MAŁGORZATA WRZESIEŃ, ${ }^{2}$ BOŻENA DENISOW}

\author{
${ }^{1}$ Department of Geobotany, Institute of Biology, Maria Curie Skłodowska University, \\ 19 Akademicka str., 20033 Lublin, Poland \\ ${ }^{2}$ Department of Botany, Agricultural University, \\ 15 Akademicka Str., 20950 Lublin, Poland
}

(Received: 1.12.2005)

\section{Su m mary}

The estimation of participation and density of forage species in several xerothermic communities of the Lublin Upland were carried out in 2004 and 2005.

Most plants species visited by bees are grouped in plots of the BrachypodioTeucrietum and the Adonido-Brachypodietum pinnati communities. The nectariferous and polleniferous taxons are mostly perennials predominated by hemicryptophytes $(79 \%)$, others are terophytes and geophytes (21\%). Successive blooming of the nectariferous and polleniferous species in both associations ensures unbroken food flow from the early spring until the late summer and early autumn. Xerothermic swards make a valuable food potential to be important for the Apoidea before and after blooming of the main forage cultivated crops.

Key words: xerothermic associations, Lublin Upland, nectariferous and polleniferous plants

\section{INTRODUCTION}

Forage plants provide the pollinating apifauna the valuable food, nectar and pollen. The development of honey bee colonies and wild bees closely depends on the food resources in the nearby habitat. Increasing environmental degradation, the vast introduction of cultivated monocultures, general agricultural intensification and chemicalization with destruction of fields margins have had an adverse influence on the lack of nectariferous and polleniferous flora. The occurrence of food gaps is being negatively reflected on the condition of honey bees families and the considerable decline of bumblebees (Bombus Latr.), solitary bees (Osmia L., Megachile L., Andrena F.), 
and other pollinators (D y le w s k a, 1995; F la g a , 2000; J a b ł on s k i, 2000). The Apoidea most frequently settle down the xerothermic swards, which create favorable conditions for existence (B a n a s z k , 1993). The communities are characterized by an extraordinarily rich and variable floristic strip creating an important element of natural and semi-natural landscapes of the whole Lublin Upland. Along with the typically grassland plants, there are also meadow, forest and forest-brush species. The xerothermic phytocenoses most frequently develop on dry slopes, grazing lands, fallows, and even on slopes of railway embankments, and anti-errosion terraces. They cover different areas, depending on the humans activity.

The aim of the research carried out on some chosen xerothermic associations was to determine their richness in nectariferous and polleniferous species. Also, the time and length of blooming of the most frequently foraged taxons were studied.

\section{MATERIAL AND METHODS}

The field research was done in 2004-2005 on three sites: Stawska Góra near Chełm, Podzamcze near Bychawa and Pliszczyn near Lublin. Patches of communities belonging to the Festuco-Brometea class, Festucetalia valesiace order and the Cirsio-Brachypodion pinnati alliance, were analyzed. To a greater or lesser degree, they represent forms resembling the complexes of the Adonido-Brachypodietum pinnati, the Brachypodio-Teucrietum and the Inuletum ensifoliae. The plant communities were identified according to the commonly accepted Braun-Blanquet's method ( $\mathrm{P}$ a w łowski, 1977).

The included phytosociological records show the species' coverage degrees in a 5-degree scale with an additional "+" marking of the species with the coverage degree lower than $10 \%$. All the examined phytocenoses are described with the same range of syntaxonomic structure (Matuszkiewicz, 2001; Fijałkowski, 1964), and the terminology of vascular plants is based on Mire k et al. (2002).

The research determined the participation of nectariferous and polleniferous plants in the individual phytocenoses of species considered to be visited by different groups of Apoidea (Apis mellifera, Bombus sp., Andrena) or Diptera. The investigated patches were visited once a week. The seasonal blooming spectrum of most intensely foraged taxons was observed according to an assumption that the beginning of the blooming period was the moment when $10 \%$ of flowers bloomed, the full of the blooming period being the $70-80 \%$ of flowers, and the end with over $75 \%$ of the flowers came out of bloom (Jabłoński and Szklanowska, 1997). The spectrum is shown as averages on the basis from investigated species observed in all patches. Also, for those species their biological stability and the Raunkiaer's life form were quoted (S z a fer, 1967; Z ar z y cki et al., 2002). The intensity of foraging were estimated as averages on the basis of 30 min observations concerning each species in every patches under consideration. Apoidea countings were made in full blooming period, during sunny weather and in most intensely forage hours (10.00-14.00 EET). The following range was applied for apifauna visits: week- $0-1 \cdot \mathrm{m}^{2}$; medium $2-4 \cdot \mathrm{m}^{2}$; good $>5 \cdot \mathrm{m}^{2}$ 
The share of nectariferous and polleniferous taxons in chosen patches of thermophilous grasslands of the Lublin Upland

Table 1

The communities Festuco Brometea class.

\begin{tabular}{|c|c|c|c|c|c|c|c|}
\hline \multicolumn{2}{|l|}{ Successive number of releve } & 1 & 2 & 3 & 4 & 5 & 6 \\
\hline \multicolumn{2}{|l|}{ Date } & 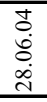 & $\begin{array}{l}n \\
0 \\
5 \\
0 \\
\\
\end{array}$ & 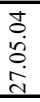 & $\begin{array}{l}n \\
0 \\
i \\
0 \\
\dot{d} \\
\end{array}$ & $\begin{array}{l}\vec{J} \\
\dot{0} \\
0 \\
\infty \\
-\end{array}$ & $\begin{array}{l}n \\
0 \\
0 \\
i \\
\end{array}$ \\
\hline \multicolumn{2}{|l|}{ Area of releve } & $\cong$ & 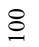 & 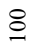 & in & 우 & 8 \\
\hline \multicolumn{2}{|l|}{ Cover of layer $\mathrm{C}$} & \& & \& & \& & \& & 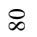 & $\infty$ \\
\hline \multicolumn{2}{|l|}{ Cover of layer B } & 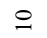 & ' & + & + & - & - \\
\hline \multicolumn{2}{|l|}{ Number of species } & 37 & 33 & 38 & 46 & 46 & 41 \\
\hline \multicolumn{2}{|l|}{ Number of forage species } & 17 & 13 & 18 & 22 & 22 & 21 \\
\hline 1 & & 2 & 3 & 5 & 6 & 7 & 8 \\
\hline \multicolumn{8}{|c|}{ I. Ch.All. Cirsio-Brachypodion pinnati } \\
\hline Inula ensifolia & & 4 & 2 & . & . & . & . \\
\hline Aster amellus & & + & + & + & 2 & . & . \\
\hline Carex michelii & & + & 1 & . & . & . & . \\
\hline Cirsium pannonicum & & 1 & + & . & . & . & . \\
\hline Melampyrum arvense & & . & . & + & + & . & . \\
\hline Ranunculus bulbosus & & . & . & + & + & + & + \\
\hline Carlina onopordifolia & & . & . & 1 & + & . & . \\
\hline Seseli annuиm & & . & . & . & . & + & + \\
\hline Carex praecox & & . & . & . & . & + & + \\
\hline \multicolumn{8}{|l|}{ II. Ch.O. Festucetalia valesiaceae } \\
\hline Salvia verticillata & & + & + & 1 & . & . & . \\
\hline Potentilla arenaria & & + & + & . & . & 1 & 1 \\
\hline Scabiosa ochroleuca & & + & + & + & + & . & + \\
\hline Thesium linophyllon & & + & + & + & + & + & . \\
\hline Campanula sibirica & & . & + & 1 & + & + & + \\
\hline Adonis vernalis & & . & . & . & . & 4 & 3 \\
\hline Achillea pannonica & & . & . & + & + & . & . \\
\hline Astragalus onobrychis & & . & . & + & + & . & . \\
\hline Campanula glomerata & & . & . & . & + & + & . \\
\hline Asparagus officinalis & & . & . & . & . & + & + \\
\hline Verbascum phoeniceum & & . & . & . & . & + & + \\
\hline Hieracium bauhinii & & . & . & . & . & + & + \\
\hline \multicolumn{8}{|l|}{ III. Ch.Cl. Festuco-Brometea } \\
\hline Brachypodium pinnatum & & + & 4 & 3 & 4 & 2 & 2 \\
\hline Centaurea scabiosa & & + & + & + & + & . & + \\
\hline Teucrium chamaedrys & & + & 1 & 1 & 1 & . & . \\
\hline Euphorbia cyparissias & & + & + & + & + & . & 1 \\
\hline Asperula cynanchica & & + & + & + & + & . & . \\
\hline Plantago media & & + & + & . & . & + & + \\
\hline Stachys recta & & + & . & + & . & . & . \\
\hline Onobrychis viciifolia & & . & . & + & + & + & . \\
\hline Carlina vulgaris & & . & . & + & + & . & . \\
\hline Anthyllis vulneraria & & . & . & + & + & + & + \\
\hline Filipendula vulgaris & & & & & + & + & \\
\hline Phleum phleoides & & . & . & . & + & + & + \\
\hline Veronica spicata & & . & . & . & + & + & + \\
\hline Acinos arvensis & & . & . & . & + & + & + \\
\hline Bromus inermis & & . & . & . & . & 1 & 1 \\
\hline Dianthus carthusianorum & & . & . & . & . & + & + \\
\hline Allium oleraceum & & . & . & . & . & + & + \\
\hline
\end{tabular}


cd. table 1

\begin{tabular}{|c|c|c|c|c|c|c|}
\hline & 1 & 2 & 3 & 4 & 5 & 6 \\
\hline Centaurea stoebe & . & . & . & . & + & + \\
\hline Artemisia campestris & . & . & . & . & + & + \\
\hline \multirow{2}{*}{\multicolumn{7}{|c|}{$\begin{array}{l}\text { Accompanying with } \\
\text { IV. Cl. Rhamno-prunetea }\end{array}$}} \\
\hline & & & & & & \\
\hline Prunus spinosa $b$ & + & . & + & + & . & . \\
\hline Rosa canina & + & + & . & . & . & . \\
\hline Cornus sanguinea $b$ & + & . & . & . & . & . \\
\hline Cerasus fruticos $a b$ & . & + & . & + & . & . \\
\hline \multicolumn{7}{|l|}{ V. Cl. Trifolio-Geranietea sanguinei } \\
\hline Peucedanum cervaria & 1 & 1 & . & . & . & . \\
\hline Geranium sanguineum & 1 & + & . & . & . & . \\
\hline Anemone sylvestris & + & + & 2 & + & . & . \\
\hline Coronilla varia & + & + & . & . & + & + \\
\hline Galium mollugo & + & + & + & + & + & + \\
\hline Leucanthemum vulgare & + & + & . & . & . & . \\
\hline Anthericum ramosum & + & 1 & . & + & + & + \\
\hline Clinopodium vulgare & + & . & . & . & + & . \\
\hline Galium verum & + & . & + & . & + & + \\
\hline Agrimonia eupatoria & + & . & + & . & + & + \\
\hline Medicago falcata & + & . & . & + & 1 & + \\
\hline Origanum vulgare & + & . & + & + & . & 1 \\
\hline Trifolium medium & . & . & . & + & + & + \\
\hline Fragaria viridis & . & . & . & + & + & . \\
\hline \multicolumn{7}{|l|}{ VII. CI. Molinio-Arrhenatheretea } \\
\hline Lotus corniculatus & + & + & . & . & + & . \\
\hline Linum catharticum & + & + & 1 & + & . & . \\
\hline Leontodon autumnalis & + & + & + & . & + & . \\
\hline Festuca rubra & + & . & . & . & . & + \\
\hline Plantago lanceolata & & + & + & + & + & \\
\hline Achillea millefolium & . & + & + & + & + & + \\
\hline Dactylis glomerata & . & + & . & . & + & + \\
\hline \multicolumn{7}{|l|}{ VIII. Others } \\
\hline Salvia pratensis & + & + & + & + & . & . \\
\hline Hypericum perforatum & + & . & . & . & + & + \\
\hline Polygala vulgaris & + & + & + & + & . & . \\
\hline Elymus repens & . & + & . & . & + & + \\
\hline Pimpinella saxifraga & & & + & + & & \\
\hline Chamaecytisus ratisbonensis & . & . & + & + & 1 & 1 \\
\hline Cerinthe minor & . & . & + & + & + & . \\
\hline Juniperus communis $b$ & . & . & + & + & . & . \\
\hline Prunella vulgaris & . & . & + & + & . & . \\
\hline Valeriana officinalis & . & . & + & + & . & . \\
\hline Primula officinalis & . & . & + & 1 & . & . \\
\hline Cruciata glabra & . & . & + & + & . & . \\
\hline Euphorbia esula & . & . & . & + & + & + \\
\hline Berteroa incana & & & & + & + & + \\
\hline Thymus serpyllum & . & . & . & . & + & + \\
\hline Sisymbrium loeselli & . & . & . & . & + & + \\
\hline
\end{tabular}

Explanation: a annual, b biennial, $\mathrm{p}$ perennial, s shrub, $\mathrm{Ch}$ chamephytes, $\mathrm{H}$ hemicryptophytes, $\mathrm{T}$ terophytes, $\mathrm{G}$ geophytes 
Table 2

The ecological featuers of forage species and visual estimation of apifauna visits.

\begin{tabular}{|c|c|c|c|c|c|}
\hline \multirow{2}{*}{ Species } & \multirow{2}{*}{$\begin{array}{l}\text { Life } \\
\text { span }\end{array}$} & \multirow{2}{*}{$\begin{array}{l}\text { Life } \\
\text { forms }\end{array}$} & \multicolumn{3}{|c|}{ Intensity of insect's visits of } \\
\hline & & & Apis mellifera $\mathrm{L}$. & Bombus sp. & Solitary bees \\
\hline Adonis vernalis & $\mathrm{p}$ & $\mathrm{H}$ & medium & good & good \\
\hline Agrimonia eupatoria & $\mathrm{p}$ & $\mathrm{H}$ & good & weak & medium \\
\hline Allium oleraceum & $\mathrm{p}$ & $\mathrm{G}$ & weak & weak & good \\
\hline Anemone sylvestris & $\mathrm{p}$ & $\mathrm{H}$ & good & medium & good \\
\hline Anthyllis vulneraria & $\mathrm{p}$ & $\mathrm{H}$ & weak & medium & weak \\
\hline Aster amellus & $\mathrm{p}$ & $\mathrm{H}$ & good & good & good \\
\hline Astragalus cicer & $\mathrm{p}$ & $\mathrm{H}$ & weak & good & eak \\
\hline Astragalus onobrychis & $\mathrm{p}$ & $\mathrm{H}$ & weak & good & weak \\
\hline Berteroa incana & $\mathrm{a}, \mathrm{p}$ & $\mathrm{T} / \mathrm{H}$ & good & weak & v. good \\
\hline Campanula sibirica & $\mathrm{b}$ & $\mathrm{H}$ & good & weak & good \\
\hline Centaurea stoebe & $\mathrm{b}$ & $\mathrm{H}$ & V. good & v. good & medium \\
\hline Centaurea scabiosa & $\mathrm{p}$ & $\mathrm{H}$ & v. good & v. good & medium \\
\hline Chamaecytisus ratisbonensis & $\mathrm{s}$ & $\mathrm{Ch}$ & weak & good & weak \\
\hline Dianthus carthusianorum & $\mathrm{p}$ & $\mathrm{Ch}$ & medium & weak & medium \\
\hline Euphorbia cyparissias & $\mathrm{p}$ & $\mathrm{G} / \mathrm{H}$ & weak & weak & good \\
\hline Euphorbia esula & $\mathrm{p}$ & $\mathrm{H}$ & weak & weak & medium \\
\hline Filipendula vulgaris & $\mathrm{p}$ & $\mathrm{H}$ & weak & weak & medium \\
\hline Fragaria viridis & $\mathrm{p}$ & $\mathrm{H}$ & medium & weak & medium \\
\hline Galium verum & $\mathrm{p}$ & $\mathrm{H}$ & good & weak & medium \\
\hline Inula ensifolia & $\mathrm{p}$ & $\mathrm{H}$ & good & good & medium \\
\hline Lotus corniculatus & $\mathrm{p}$ & $\mathrm{H}$ & weak & good & weak \\
\hline Medicago falcata & $\mathrm{p}$ & $\mathrm{H}$ & good & good & weak \\
\hline Melampyrum arvense & $\mathrm{a}$ & $\mathrm{T}$ & weak & good & weak \\
\hline Onobrychis viciifolia & $\mathrm{p}$ & $\mathrm{H}$ & weak & good & weak \\
\hline Origanum vulgare & $\mathrm{p}$ & $\mathrm{H}$ & v. good & medium & good \\
\hline Pimpinella saxifraga & $\mathrm{p}$ & $\mathrm{H}$ & weak & weak & good \\
\hline Potentilla arenaria & $\mathrm{p}$ & $\mathrm{H}$ & good & weak & good \\
\hline Ranunculus bulbosus & $\mathrm{p}$ & $\mathrm{G}$ & weak & weak & medium \\
\hline Salvia pratensis & $\mathrm{p}$ & $\mathrm{H}$ & good & good & good \\
\hline Salvia verticillata & $\mathrm{p}$ & $\mathrm{H}$ & good & good & medium \\
\hline Scabiosa ochroleuca & $\mathrm{p}$ & $\mathrm{H}$ & good & good & medium \\
\hline Stachys recta & $\mathrm{p}$ & $\mathrm{H}$ & good & weak & good \\
\hline Teucrium chamaedrys & $\mathrm{p}$ & $\mathrm{Ch}$ & good & weak & good \\
\hline Thymus serphyllum & $\mathrm{p}$ & $\mathrm{Ch}$ & good & weak & good \\
\hline Trifolium medium & $\mathrm{p}$ & $\mathrm{H}$ & v. good & good & good \\
\hline Verbascum phoeniceum & $\mathrm{b}$ & $\mathrm{H}$ & good & good & good \\
\hline Veronica spicata & $\mathrm{p}$ & $\mathrm{H}$ & weak & weak & good \\
\hline
\end{tabular}




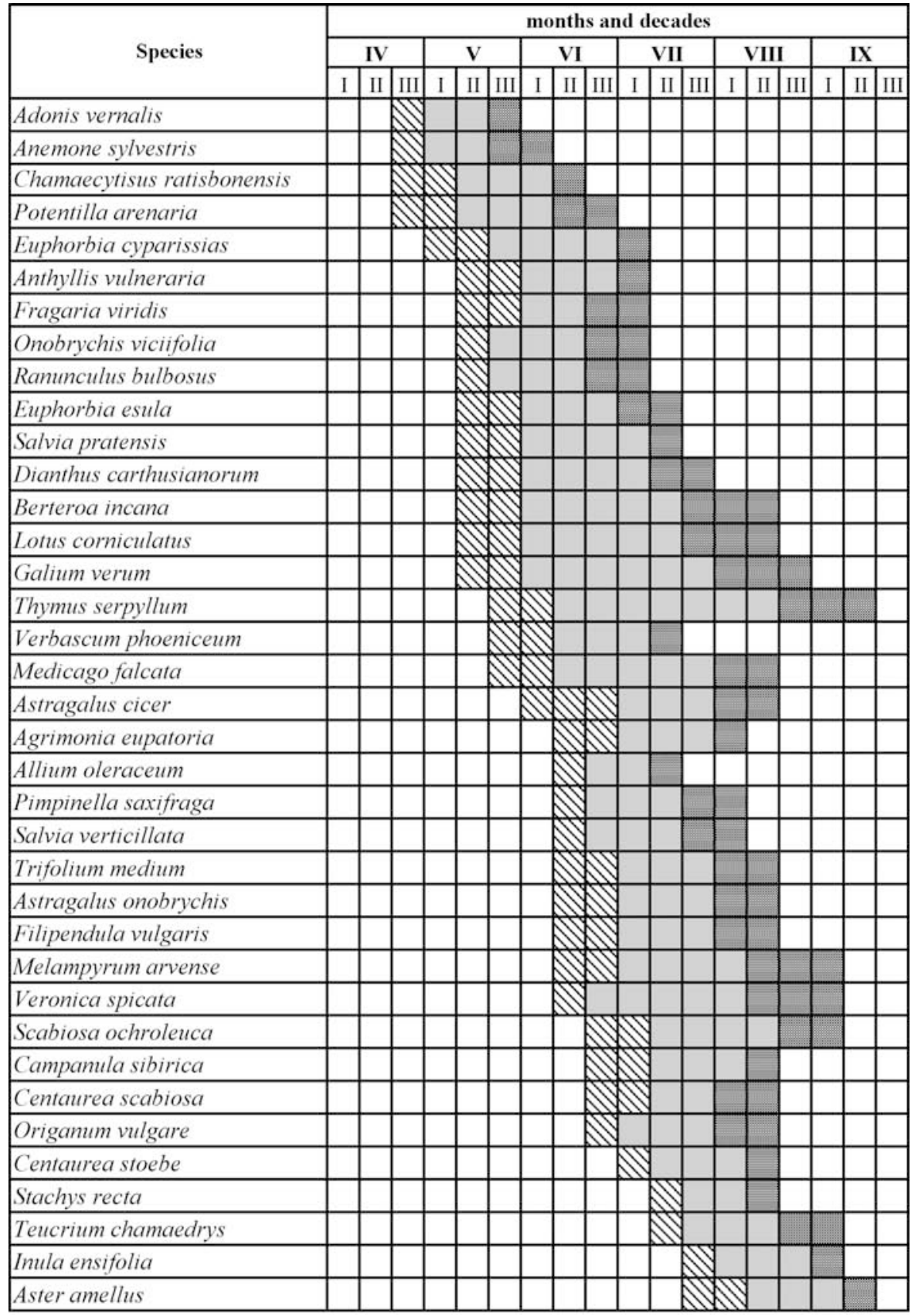

Stages of blooming: $\quad \square$ beginning $\square$ full $\square$ end

Fig. 1. The blooming spectrum of nectariferous and polleniferous species in investigated xerotermic patches (averages from years of studies). 


\section{RESULTS}

The phytosociological records taken allowed the distinction of three basic associations and degree of nectariferous and polleniferous species' coverage. The blooming phases along with the description of their life span and life form are shown (Table 1, 2, Fig 1, records 1-6).

\section{Inuletum ensifoliae (Table 1, records 1-2)}

This association is connected with eroded chalky slops of different inclination. The patches are clearly predominated by Inula ensifoliae (up to $80 \%$ of the coverage), which is associated by typical xerothermic taxons such as Aster amellus and Cirsium pannonicum. The nectariferous and polleniferous plants, e.g. Anthericum ramosum, Campanula glomerata, Euphorbia cyparisias, Galium verum, Peucedanum cervaria Potentilla arenaria, Teucrium chamaedrys, etc. which are present do not reach high degrees of coverage. The hard core of this association is formed by the species blooming at the mid and late summer or early autumn, and there is a lack of typical harbingers of spring, present in the other two associations.

\section{Brachypodio-Teucrietum (Table 1, records 3-4)}

The association is characterized by the highest floral variability and a great share of species with coverage achieving 10\%. The appearance of Brachypodio-Teucrietum patches changes quite considerably in different phenological periods, which results from the seasonal growth and blooming of individual species which create the herbaceous layer. In the early spring its colour comes from Anemone sylvestris, Chamaecytisus ratisbonensis, Euphorbia cyparisias, Potentilla arenaria and Primula officinalis. Then Cerinthe minor, Campanula sibirica, Centaurea scabiosa, Hieracium bauhinii, Melampyrum arvense, Onobrychis viciaefolia, Origanum vulgare, Ranunculus bulbosus, Pimpinella saxifraga, Salvia verticillata, Thesium linophyllum, Valeriana officinalis join in the flowering. The majority of these plants form dense clumps in which there are individual plants of Agrimonia eupatoria, Centaurea stoebe, Dianthus carthusianorum, Scabiosa ochroleuca, the species frequently visited by entomofauna. Despite the typical xerothermic species, a constant and quantitatively considerable additives are the heliophytes of the edge communities of the Trifolio-Geranietea sanguinei class. In total 20 plant species visited by bees has been found in observed association. The association can be very important as a potential pollen and nectar resource providing Apoidea with food, continually from early spring until the mid summer.

\section{Adonido-Brachypodietum pinnati (Table 1, records 5-6)}

The phytosociological records taken on the intrafield slopes grown by herbaceous vegetation in Pliszczyn near Lublin distinguish the phytocenosis which was also classified as the Festuco vallesiaceae-Erysimum crepidifolium (I z d e b s k i, 
1958). According to Mat u s zkiew ic z (2002), it can constitute the impoverished form of the Thalictro-Salvietum, devoid of many rare but characteristic species or the Brachypodio-Teucrietum distinguished by Fijałk ow ski (1969). Apart from the small surface of the escarpment, the density of its flora within the analyzed patch was considerable. In the early spring, it takes the form of a yellow carpet predominated with Adonis vernalis (up to $60 \%$ of the cover), Potentilla arenaria and Chamaecytisus ratisbonensis. At the full pick of spring, the violet and blue of the flowers of Verbascum phoeniceum, Salvia pratensis, Campanula sibirica, Plantago media start ruling over the patch. In the summer, apart from dense clumps of Medicago falcata, Galium verum and Trifolium montanum, there are some smaller amounts of Dianthus carthusianorum, Centaurea stoebe, Scabiosa ochroleuca. Later, the slopes start turning brown with shedding Bromus inermis and Elymus repens. Similarly, as in the Brachypodio-Teucrietum, in spite of the typical xerothermic species, there are some representatives of the Molinio-Arrhenatheretea and the Trifolio-Geranietea sanguinei classes. A total of 23 forage plants species was observed, which is $50 \%$ of the herbaceous vegetation, on average.

\section{CONCLUSIONS}

1. The greatest participation of the nectariferous and polleniferous species is located in the patches of Brachypodio-Teucrietum and the Adonido-Brachypodietum pinnati. Both associations are distinguished with a great floral variability and with a considerable density of taxons blooming in the early spring seasonal aspect.

2. Adonis vernalis, Anemone sylvestris, Chamaecytisus ratisbonensis, Centaurea scabiosa, Origanum vulgare, Potentilla arenaria, Salvia verticillata, Teucrium chamaedrys were found among the foraged species located in the xerothermic associations of the studied area. These species form a great coverage and are most intensely visited by bees.

3. The successive phenology of blooming of plant species which constitute the xerothermic swards provides Apoidea with unbroken food flow throughout the whole vegetation season, in the period between the early spring to the late summer and early autumn.

4. Perennials constitute $77 \%$ of a forage flora. Among them the hemicryptophytes predominate (79\%), others are terophytes and geophytes (in total $21 \%$ ). Such an arrangement confirms the stability and relative persistence of the xerothermic grasslands.

5. The patches of xerothermic associations should be protected not only because of the floral richness and the presence of the rare species but also the presence of nectariferous and polleniferous taxons. The herbaceous xerothermic vegetation supply the Apoidea with food in the critical periods of shortage of nectar and pollen before and after blooming of the main cultivated crop food providers. 


\section{REFERENCES}

B a n a s z a k J., 1993. Ekologia pszczół. PWN, Poznań.

Fi j ałk ow s k i D., 1964. Zbiorowiska kserotermiczne okolic Izbicy na Wyżynie Lubelskiej, Ann. Univ. Mariae Curie Skłodowska sect. C Biol. 19:239 259.

F i j a ł k o w s k i D., 1969. Zespoły kserotermiczne Lubelszczyzny, Biul. Lub. Tow. Nauk., 9: 2732. Fij ał k ow sk i D., 1972. Stosunki geobotaniczne Lubelszczyzny. Lub. Tow. Nauk., Ossoli neum, Wrocław.

Fla g a S., 2000. Ocena wpływu struktury upraw i stosowanych w rolnictwie technologii pro dukcji na faunę pszczół. Polski Klub Ekologiczny, Kraków.

I z d e b s k i K., 1958. Badania fitosocjologiczne i florystyczne w rezerwacie Stawska Góra pod Chełmem. Ann. Univ. Mariae Curie Skłodowska, sect. D, 22:213 230.

J a błońs ki B., 2000. O potrzebie i możliwościach poprawy pożytków pszczelich. Oddz. Pszczeln. ISK, Puławy.

J a błoń s ki B., S z k l a n o w s k a K., 1997. Wpływ niektórych czynników pogody na kwit nienie, nektarowanie, pylenie i oblot przez owady zapylające entomofilnych roślin upraw nych. LTN, Lublin: 5358.

M a t u s z k i e w i c z W., 2001. Przewodnik do oznaczania zbiorowisk roślinnych Polski. Vade mecum geobotanicum 3. ss 537. Wydawnictwo Naukowe PWN, Warszawa.

Mirek Z., Piękoś Mirkowa H., Zając A., Zając M., 2002. Flowering plants and pteridophytes of Poland. A checlist. Biodiversity of Poland 1, ss 442. W. Szafer Institute of Botany, Polish Academy of Sciences, Kraków.

P a w ł o w s k i B., 1977. Skład i budowa zbiorowisk roślinnych oraz metody ich badania. [w:] W. Szafer \& K. Zarzycki (red.), Szata roślinna Polski. 1. ss. 237 267. PWN, Warszawa.

S z a f e r W., K u lc z y c ki S., P a w ł ow s k i B. 1967. Rośliny polskie. Państwowe Wydaw nictwo Naukowe, Warszawa.

Zarzycki K., Trzcińska Tacik H., Różański W., Szeląg Z., Wołek J., Ko rzeniak U., 2002. Ecological indicator values of vascular plants of Poland. Polish Academy of Sciences, Kraków.

\section{Udział roślin pożytkowych w wybranych płatach muraw kserotermicznych Wyżyny Lubelskiej}

\section{Streszczenie}

Badania dotyczące obecności roślin pożytkowych w kilku zbiorowiskach muraw ciepłolubnych Wyżyny Lubelskiej prowadzono w sezonach wegetacyjnych 2004-2005.

Najwięcej gatunków oblatywanych przez pszczołowate grupuje się w fitocenozach Brachypodio-Teucrietum i Adonido-Brachypodietum pinnati. W większości są to rośliny wieloletnie, wśród których zdecydowanie przeważają hemikryptofity (79\%). Pozostałe gatunki to terofity i geofity (łącznie 21\%). Sukcesywne kwitnienie gatunków pożytkowych w obu zespołach zapewnia ciągłość taśmy pokarmowej od wczesnej wiosny do późnego lata, a nawet wczesnej jesieni. Asocjacje muraw kserotermicznych stanowią cenny rezerwuar pokarmu, który może być wykorzystywany przez Apoidea przed i po kwitnieniu pożytkowych roślin uprawnych. 
